\title{
Asymptomatic airway hyperresponsiveness: relationships with airway inflammation and remodelling
}

\author{
C. Laprise*, M. Laviolette*, M. Boutet ${ }^{+}$, L.-P. Boulet*
}

\begin{abstract}
Asymptomatic airway hyperresponsiveness: relationships with airway inflammation and remodelling. C. Laprise, M. Laviolette, M. Boutet, L.-P. Boulet. (C) ERS Journals Ltd 1999. ABSTRACT: To study the physiopathology and significance of asymptomatic airway hyperresponsiveness (AHR), the clinical and bronchial immunohistological parameters were evaluated in subjects with asymptomatic and symptomatic AHR.

Asymptomatic subjects with AHR (eight females/two males, no respiratory symptoms, provocative concentration of methacholine causing a $20 \%$ fall in forced expiratory volume in one second (PC20) $<8 \mathrm{mg} \cdot \mathrm{mL}^{-1}$ and no treatment) were compared with asthmatic subjects paired for age, sex and PC20, and with nonatopic, nonasthmatic controls paired for age and sex. All three groups were evaluated once at baseline, whilst the asymptomatic AHR subjects were re-evaluated after 1 and 2 yrs. Measurements included spirometry, methacholine challenge, serum immunoglobulin (Ig)E, blood eosinophils, and bronchoscopy (at baseline and after 2 yrs only).

At first evaluation, the mean blood eosinophil count, total serum IgE level, atopic index, baseline forced expiratory volume in one second (FEV1) and the degree of bronchial epithelial desquamation of the asymptomatic AHR subjects were similar to those of asthmatic subjects. However, they presented focal rather than the continuous bronchial subepithelial fibrosis observed in asthmatics. Their mucosal CD3, CD4, CD25, EG1 and EG2-positive cell counts were intermediate between those of the control subjects and asthmatics. At the end of the 2-yr follow-up, four of them had developed asthma symptoms. At this time, bronchial biopsies revealed an increase in the extent of subepithelial fibrosis and in the number of CD25 and CD4-positive cells, and a decrease in the number of CD8+ cells, particularly in subjects who developed asthma symptoms.

These data suggest that asymptomatic airway hyperresponsiveness is associated with airway inflammation and remodelling, and that the appearance of asthma symptoms is associated with an increase in these features, particularly the CD4/CD8 ratio and airway fibrosis. Consequently, this study proposes an association between asymptomatic airway hyperresponsiveness and airway inflammation, structural changes and asthma although these relationships remain to be further evaluated. Eur Respir J 1999; 14: 63-73.
\end{abstract} \author{
Foy, Québec, Canada. \\ Correspondence: L.-P. Boulet \\ Hôpital Laval \\ 2725, Chemin Sainte-Foy \\ Sainte-Foy \\ Québec \\ G1V 4G5 Canada \\ Fax: 4186564762
}

*Centre de pneumologie de l'Hôpital Laval, and ${ }^{+}$Laboratoire de pathologie de l'Hôpital Laval, Université Laval, Sainte-

Keywords: Airway inflammation

asthma

asymptomatic airway

hyperresponsiveness

bronchial biopsies

lymphocyte

Received: February 281998

Accepted after revision October 301998

This work was supported by a grant from the Centre québécois d'excellence en santé respiratoire (FRSQ, GlaxoWellcome). C. Laprise was supported by the "Fonds pour la formation de Chercheurs et $\mathrm{l}^{\prime}$ Aide à la Recherche (FCAR) du Québec".
Airway hyperresponsiveness (AHR), a characteristic feature of asthma, describes the tendency of the bronchi to narrow too much and too easily in response to provocative stimuli [1]. However, the relationship between AHR and respiratory symptoms is not always strong: $\sim 50 \%$ of subjects with AHR report no respiratory symptoms $[1,2]$. AHR may precede asthma and seems to be a risk factor in the development of this disease in children [3]. The clinical significance of asymptomatic AHR and its relationship with asthma remain, however, to be further documented. Previous studies have shown that, in firstdegree relatives with asthma, the prevalence of AHR may exceed $75 \%$ and persist for several years without symptoms [4-6], suggesting a familial trait [2]. A significant association between the degree of airway responsiveness and the severity of atopy was also found in nonasthmatic atopic subjects [7]. COCKCROFT et al. [8] found that 9.2\% of young atopic nonasthmatic adult subjects presented with AHR, while BRAMAN et al. [9] reported AHR in 40\% of nonasthmatic subjects with rhinitis (aged 12-54 yrs).
In a recent study [10], it was observed that four out of 28 of the asymptomatic AHR subjects (age mean \pm SD $31.6 \pm$ $2.8 \mathrm{yrs}$ ) developed asthma symptoms over a 3 -yr period. These four subjects were exposed to allergens to which they were sensitized (high atopic score) and had at least one first-degree relative with asthma, suggesting that atopy and heredity were implicated in the development of asthma symptoms.

Airway inflammation is considered to be the main pathogenetic mechanism of asthma [11]. Compared to those of normal subjects, bronchial biopsies of asthmatics typically show mucosal oedema, desquamation of the epithelium, subepithelial fibrosis, and infiltration by mast cells, eosinophils and lymphocytes [12]. In this regard, several studies using bronchial biopsies to explore basic mechanisms leading to asthma showed signs of damage to the surface epithelium $[13,14]$, subepithelial fibrosis [14] and an increase in the number of airway wall inflammatory cells early in the course of the disease $[14,15]$. In addition, immunohistological studies showed increased 
activation of lymphocytes and eosinophils, suggesting that these cells play an important role in the inflammatory and structural changes observed [15].

Although the role of inflammation in the development of asthma symptoms seems well established, the importance of resulting structural changes is also increasingly recognized. The situation, however, is more controversial with asymptomatic AHR. Power et al. [16] previously reported that there was no evidence of airway inflammation in subjects with asymptomatic AHR. However, some of these subjects may show a progressive increase in airway responsiveness and may develop asthma symptoms. It is possible that these asymptomatic subjects already had some airway inflammation and remodelling and that a progression of these early processes will eventually result in the development of symptomatic asthma.

It was therefore of interest to look at airway inflammatory and structural changes in the present group of subjects with asymptomatic AHR, specifically in relation to atopy and heredity. The purpose of this study was to evaluate the presence of airway inflammation and/or remodelling in asymptomatic AHR, and the evolution of these three components over time.

\section{Subjects and methods}

\section{Subjects}

A total of 30 subjects volunteered for this study. A group of subjects with asymptomatic AHR $(n=10)$ were recruited from a cohort of 28 subjects with asymptomatic AHR identified during a recent study on the prevalence of AHR and atopy in families of asthmatic subjects, compared with control families [10]. Ten subjects with asymptomatic AHR (two male, eight female) who agreed to have bronchoscopies with bronchial biopsies were enrolled in this study; five of these were highly atopic and five nonatopic. All denied any past symptoms suggestive of asthma (including recurrent cough) and had a provocative concentration of methacholine causing a $20 \%$ fall in forced expiratory volume in one second $(\mathrm{PC} 20)<8 \mathrm{mg} \cdot \mathrm{mL}^{-1}$. They had had no respiratory infection in the month preceding this study.

A second group of subjects with current mild symptoms of asthma $(n=10)$, receiving only intermittent inhaled bronchodilator, was recruited from the Laval Hospital asthma clinic; these subjects were matched for PC20, age and sex to the subjects with asymptomatic AHR. Asthmatic subjects were stable at the time of the study and had not used inhaled corticosteroids in the previous three months. In the month preceding this study, they had had neither respiratory infection nor asthma exacerbation.

A control group of 10 subjects, matched for age and sex to the asymptomatic AHR subjects, were also studied. Selection criteria for this group were: $\mathrm{PC} 20>20 \mathrm{mg} \cdot \mathrm{mL}^{-1}$, no current or past symptoms suggesting asthma or other respiratory disease, no medication and no respiratory infection in the prior month.

The study was approved by the Laval Hospital Ethics Committee and all subjects signed informed consent forms.

\section{Definitions}

Asthma was defined according to the criteria suggested by the American Thoracic Society (ATS) [17]. Asymptomatic AHR was also defined as a $\mathrm{PC} 20<8 \mathrm{mg} \cdot \mathrm{mL}^{-1}$ in the absence of symptoms suggestive of asthma in subjects who never required any asthma medication [18]. Atopy was defined as the presence of at least one positive response (weal diameter $\geq 3 \mathrm{~mm}$ at $10 \mathrm{~min}$ ) to skinprick tests with a battery of 26 common airborne allergens [19]. Skin prick tests were performed with a battery of airborne allergens, which were divided into six main categories: animal danders, dust, housedust mite, tree pollen, grass pollen and moulds. The atopic index was determined as the number of aeroallergen categories $(0-6)$ to which the patient showed at least one positive response on allergy skin test.

\section{Design}

All three groups of subjects were evaluated once at baseline (first visit). The asymptomatic AHR subjects were re-evaluated at the end of 1- and 2-yr periods in FebruaryMarch (in order to avoid the pollen season), repeating the same tests as on baseline evaluation. Bronchoscopy was performed at the baseline evaluation in each group and repeated at the end of the 2-yr follow-up in the asymptomatic AHR group.

\section{Clinical evaluation}

Expiratory flows were measured with a Vitalograph PFT II spirometer(VitalographMedical Instrumentation, Lenexa, KS, USA) according to ATS recommendations [20]. The best of three forced expiratory volume curves was used to determine forced vital capacity (FVC) and forced expiratory volume in one second (FEV1). Bronchodilator response was measured as the increase in FEV1, 15 min after $200 \mu \mathrm{g}$ of inhaled salbutamol. Peak expiratory flows (PEF) were measured with a Mini-Wright peak-flow meter (Armstrong Medical, Scarborough, Ontario, Cana$\mathrm{da}$ ) in the morning and evening during a 2 -week period. The best of three repeated measurements was recorded.

Methacholine inhalation tests were carried out according to the method described by JUNIPER et al. [21]. The results were expressed as the PC20, by intrapolation from the dose-response curve. During this test, chest symptoms (perceived bronchoconstriction) were measured on a modified perception scale from 0 (nothing) to 10 (maximal).

Subjects underwent skin prick tests with a battery of airbone allergens divided into categories (see Definitions section) and the atopic index was the number of aeroallergen categories (0-6) to which the subject showed at least one positive response. Immunoenzymofluorometry was used to measure serum immunoglobulin (Ig)E, and blood eosinophils were counted on a Coulter STKS (Coulter STKS, Hialeah, FL, USA).

\section{Bronchoscopy and bronchial biopsies}

Before the bronchoscopy, asthmatic subjects received a $200 \mu \mathrm{g}$ dose of inhaled salbutamol via a metered-dose 
inhaler. For all subjects, the procedure was performed with supplementary oxygen given at $5 \mathrm{~L} \cdot \mathrm{min}^{-1}$ by a nasal catheter. After local anaesthesia with $2 \%$ and $4 \%$ xylocaine, a flexible bronchoscope (Olympus OES 10 fibrescope, Olympus, Optical Go Ltd, Tokyo, Japan) was introduced into the bronchial tree and tissue samples were taken from the carinae of lobar and segmental bronchi using conventional forceps. Vital signs, electrocardiograph and oximetry were recorded throughout the procedure.

\section{Histology}

Tissue processing. For histological analysis, biopsies were fixed in phosphate-buffered formalin, dehydrated in alcohol and embedded in paraffin. Sections, $4 \mu \mathrm{m}$ thick, were stained with haematoxylin and eosin (H \& E), Giemsa and Weigert-Masson trichrome.

\section{Electron microscopy}

Samples for electron microscopy analysis were fixed by immersion in Karnovsky's fluid, washed in cacodylate buffer, stained with osmium tetraoxide, dehydrated in alcohol and embedded in Epon [22]. Half of the samples were treated en bloc with uranyl acetate. All sections were stained with lead citrate and analysed using a Jeol 100 CX electron microscope (Tokyo, Japan). Electron microscopic studies evaluated cellular alterations of epithelial and connective tissue cells as well as the presence of myofibroblasts; they were also used to assess degranulation of eosinophils and mast cells. No counts were made from electron micrographs.

\section{Immunochemistry}

Tissue processing. Biopsies were immediately placed in acetone containing the protease inhibitors phenylmethylsulphonyl fluoride $(2 \mathrm{mM})$ and iodoacetamide $(2 \mathrm{mM})$ (Sigma Chemical Co., St Louis, MO, USA) and cooled rapidly to $-20^{\circ} \mathrm{C}$. They were then immersed in acetone at room temperature for $15 \mathrm{~min}$ and transferred to methylbenzoyl for another $15 \mathrm{~min}$. Thereafter, the biopsies were immersed in glycolmethacrylate (GMA) monomer (Polyscience, Warrington, PA, USA) at $4^{\circ} \mathrm{C}$ for $7 \mathrm{~h}$. During this time, the GMA solution was changed three times. Finally, bronchial biopsies were embedded in GMA resin prepared by mixing GMA monomer and $N$, $N$-dimethylalanine in polyethylene glycol PEG 400 and benzol peroxide, and polymerized overnight at $4{ }^{\circ} \mathrm{C}$ [23]. Samples embedded in GMA were stored at $-20^{\circ} \mathrm{C}$ in an airtight container. Sections, $2 \mu \mathrm{m}$ thick, were cut on an ultramicrotome (Leica Reichert Ultracut S, Austria) and floated on water containing $0.02 \%$ ammonia until fixed on poly-L-lysine-coated slides [23]

\section{Quantification of immunohistochemical staining}

The following monoclonal antibodies (dilutions) were used: CD4 (1:25), CD8 (1:50) (Becton Dickinson, San Jose, USA, CA); CD3 (undiluted), CD25 (1:25), human leukocyte antigen (HLA)-DR (1:200), CD45 (1:100),
CD45Ro (1:50) (DAKO; Dimension Laboratories, Mississauga, Ontario, Canada); EG1 (1:100), EG2 (1:200) (Kabi Pharmacia Diagnostics, Baie d'Urfé, Québec, Canada); AA1 (1:400) (kindly provided by S.T. Holgate, University of Southampton, UK). Expression of these markers (monoclonal antibody staining) was detected by the avidin biotin complex (ABC method) using amino ethyl carbazole (AEC) as the chromogen (Vectastain Elite ABC kit, Vector Laboratories, Burlingame, CA, USA).

Briefly, samples were blocked for background peroxidase activity with $0.3 \% \mathrm{H}_{2} \mathrm{O}_{2}$ and $1 \%$ sodium azide in Tris buffeed saline (TBS) for $30 \mathrm{~min}$ and blocked with normal serum for $30 \mathrm{~min}$. The samples were then incubated overnight with primary antibody $\left(4^{\circ} \mathrm{C}\right), 1 \mathrm{~h}$ with a biotinylated secondary antibody $\left(23^{\circ} \mathrm{C}\right)$ and $30 \mathrm{~min}$ with the $\mathrm{ABC}$ method $\left(23^{\circ} \mathrm{C}\right)$. The slides were washed three times between each step with TBS. Visualization was carried out using the AEC substrate until coloration was visible. The reaction was stopped by washing in water, and Mayer haematoxylin was used for counterstaining. Slides were mounted with Crystal mount (Biomeda, Foster City, CA, USA). Negative controls were included in each staining run by omission of the primary antibody.

\section{Cell quantification}

The biopsy area was measured with a calibrated image analyser (Mocha image analysis Software; Jandel Scientific, San Raphael, CA, USA), and tissue cell counts were expressed per square millimetre of subepithelial connective tissue excluding smooth-muscle cells and mucous glands. Cells were counted only if nuclei were present, as previously described [23].

\section{Statistical analysis}

Results are expressed as mean \pm SEM values for FEV1, atopic score and blood eosinophil counts. Total serum IgE level and $\mathrm{PC} 20$ are expressed as the geometric mean \pm SEM. If $\mathrm{PC} 20$ was $>256 \mathrm{mg} \cdot \mathrm{mL}^{-1}$, it was considered to be 256 $\mathrm{mg} \cdot \mathrm{mL}^{-1}$ for analysis. In the asymptomatic AHR group, the change in the number of doubling concentrations of $P C 20$ was calculated with the following formula: $P C 20=\log _{10}$ PC20 at yr $1-\log _{10}$ PC20 at yr $3 / \log _{10}$ PC20 at yr 2 . For continuous variables, a one-way analysis of variance (ANOVA) was used to compare mean values between groups of subjects. In order to identify significant differences between groups of subjects (asymptomatic AHR, asthma and control), the means were compared using Scheffe's method. Paired results (at 1 and 3 yrs) were analysed using a repeated measures design. Categorical variables were analysed with the Fisher's exact test to determine the association between various variables. Significance was accepted at $\mathrm{p}<0.05$.

\section{Results}

\section{Subject characteristics}

The asymptomatic AHR subjects were aged 18-52 yrs (mean \pm SEM $25.1 \pm 3.2$ ), and as determined by the inclusion 
Table 1. - Subjects characteristics

\begin{tabular}{|c|c|c|c|c|c|c|c|c|c|c|}
\hline Groups & $\begin{array}{l}\text { Sex } \\
\text { F/M }\end{array}$ & $\begin{array}{l}\text { Age }^{\dagger} \\
\text { yrs }\end{array}$ & $\begin{array}{l}\text { Eosinophils }^{\dagger} \\
\times 10^{9} \text { cells } \cdot \mathrm{L}^{-1}\end{array}$ & $\frac{\operatorname{IgE}}{\mathrm{mg} \cdot \mathrm{L}^{\dagger}}$ & $\begin{array}{l}\text { Atopic } \\
\text { index }^{\star \S}\end{array}$ & $\begin{array}{l}\mathrm{FEV}_{1}^{\dagger} \\
\% \text { pred }\end{array}$ & $\begin{array}{l}\text { Bronchodilator } \\
\text { response } \% \\
\text { change in FEV1 }\end{array}$ & $\begin{array}{c}\text { PEF } \\
\text { variability } \\
\text { mean daily } \\
\%\end{array}$ & $\begin{array}{c}\mathrm{PC} 20^{+} \\
\mathrm{mg} \cdot \mathrm{mL}^{-1}\end{array}$ & $\begin{array}{c}\text { Perception } \\
\text { score } \\
0-10\end{array}$ \\
\hline Controls & $8 / 2$ & $26 \pm 2.7$ & $0.06 \pm 0.02^{\mathrm{a}}$ & $25.7 \pm 1.7^{\mathrm{a}}$ & $0 \pm 0^{\mathrm{a}}$ & $107.3 \pm 2.5^{\mathrm{a}}$ & $1.5 \pm 0.5^{\mathrm{a}}$ & $2.7 \pm 0.3^{\mathrm{a}}$ & $104.5 \pm 1.7^{\mathrm{a}}$ & $3.1 \pm 0.2^{\mathrm{a}}$ \\
\hline AAHR & $8 / 2$ & $25 \pm 3.2$ & $0.23 \pm 0.04^{\mathrm{b}}$ & $178.7 \pm 1.3^{b}$ & $2.8 \pm 0.8^{b}$ & $95 \pm 2.4^{\mathrm{b}}$ & $3.8 \pm 0.7^{\mathrm{a}}$ & $5.1 \pm 0.7^{b}$ & $3.6 \pm 1.1^{\mathrm{b}}$ & $2.9 \pm 0.2^{\mathrm{a}}$ \\
\hline Asthma & $8 / 2$ & $26 \pm 3.2$ & $0.20 \pm 0.04^{\mathrm{b}}$ & $129.1 \pm 1.3^{\mathrm{b}}$ & $3.6 \pm 0.8^{b}$ & $89.1 \pm 4.5^{\mathrm{b}}$ & $7.7 \pm 1.4^{\mathrm{b}}$ & $5.8 \pm 0.8^{b}$ & $3.0 \pm 1.1^{\mathrm{b}}$ & $1.2 \pm 0.3^{\mathrm{b}}$ \\
\hline
\end{tabular}

For group comparisons, values identified by a different letter are different $(\mathrm{p}<0.05)$. AAHR: asymptomatic airway hyperresponsiveness; F: female; M: male; IgE: immunoglobulin E; FEV1: forced expiratory volume in one second; PEF: peak expiratory flow; PC20: provocative concentration of methacholine causing a $20 \%$ fall in FEV1. ${ }^{\dagger}$ : expressed as mean \pm SEM; ${ }^{\dagger}$ : expressed as geometric mean \pm SEM; ${ }^{\S}$ : number of mean categories of allergens presenting at least one positive response (total of six categories).

criteria, had a similar $\mathrm{PC} 20$ to asthmatic subjects (geometric mean PC20 3.6 $\pm 1.1 \mathrm{mg} \cdot \mathrm{mL}^{-1}$ and $3.0 \pm 1.1 \mathrm{mg} \cdot \mathrm{mL}^{-1}$, respectively). They did not differ significantly from controls with regard to perception of symptoms $(2.9 \pm 0.2 \mathrm{ver}-$ sus $3.1 \pm 0.2, \mathrm{p}=0.36)$ and bronchodilator response $(3.8 \pm 0.7$ versus $1.5 \pm 0.5, \mathrm{p}=0.15$; table 1$)$. Their variability of $\mathrm{PEF}$ was greater than that observed in the control group ( $5.1 \pm 0.7$ versus $2.7 \pm 0.3, \mathrm{p}=0.008)$, as were the serum $\mathrm{IgE}$ levels $(178.7 \pm 1.3$ versus $25.7 \pm 1.7, \mathrm{p}=0.004)$ and blood eosinophils count $(0.23 \pm 0.04$ versus $0.06 \pm 0.02, p=0.0005$; table 1). They had a weaker bronchodilator response than the asthmatic subjects (\% change in FEV1 $3.8 \pm 0.7$ versus $7.3 \pm 1.4, \mathrm{p}=0.04$; table 1 ). Finally, they perceived methacholine-induced bronchoconstriction more acutely than the asthmatic subjects (perception score $2.9 \pm 0.2$ and $1.2 \pm$ 0.3 , respectively, $\mathrm{p}<0.0001)$.

Six of the asymptomatic AHR subjects were exposed to domestic animals at the time of the study (three to cats, two to dogs and one to cat and dog). Five $(50 \%)$ of the asymptomatic AHR subjects had positive allergic skin tests to indoor allergens (house dust, cat hair epithelium, dog hair danders and Dermatophagoides farinae) and the mean of atopic index for those five subjects was $4.7 \pm 0.6$. Three of these five subjects were also sensitized to outdoor allergens (mixed trees, mixed grasses and/or ragweed pollens). These five subjects, unlike the other asymptomatic AHR subjects, had a family history of asthma and atopy.

Mild asthmatic subjects were aged 20-52 yrs (mean \pm SEM 26.4 \pm 3.2 ). They had normal expiratory flows (mean FEV1 $89.1 \pm 4.5 \%$ pred) (table 1). Six (60\%) subjects had positive allergic skinprick tests to housedust mite and five of these subjects to animal danders and tree, grass and/or ragweed pollens. The mean atopic index of these subjects was $5.3 \pm 0.3$. All had a family history of atopy and nine had a first-degree relative with asthma. None were exposed to animals.

Normal controls were aged 19-51 yrs (mean \pm SEM $25.9 \pm 2.7$ ) and had a geometric mean PC20 of $104.5 \pm 1.7$ $\mathrm{mg} \cdot \mathrm{mL}^{-1}$ (table 1$)$. None had a family history of asthma or atopy, and seven were exposed to domestic animals.

\section{Comparative histopathological analysis}

Airway histological changes. On light microscopy, bronchial biopsies of the control group showed normal pseudostratified ciliated epithelial cells with goblet cells and basal triangular cells. Epithelial cells were regularly distributed, and had numerous cilia (mean \% epithelial desquamation $17.7 \pm 3.5$ ). The basement membrane was thin (mean value $4.4 \pm 0.1 \mu \mathrm{m}$ ) and a few scattered inflammatory cells, mostly lymphocytes, eosinophils and mast cells, were observed in subepithelial connective tissue. No subepithelial fibrosis could be observed in control subjects (fig. 1A). Electron microscopy of the epithelial layer (fig. 1E) showed numerous cilia at the apical portion of cylindrical cells. Numerous goblet cells were present and the basement membrane was thin and devoid of reticulocollagen fibres (subepithelial fibrosis). Lymphocytes were sparse, and eosinophils and nondegranulated mast cells were seen.

Biopsies of asthmatic subjects showed epithelial desquamation (mean epithelial desquamation of $54.4 \pm 3.7 \%$ ), but basal cells remained attached to basement membrane (fig. 1B). Subepithelial fibrosis was noted in asthmatic subjects as shown by a regular deposition of collagen fibres under the basement membrane (mean thickness 7.0 \pm 2.2 $\mu \mathrm{m})$. Oedema of connective tissue was associated with vascular congestion and an inflammatory cell infiltrate, mostly of lymphocytes (fig. 1B). On electron microscopic analysis, the remaining cylindrical cells presented decreased formation of cilia, swollen mitochondriae and dilatation of smooth endoplasmic reticulum. Mast cells and eosinophils were often seen and were frequently degranulated.

In the asymptomatic AHR group, the mean percentage of epithelial desquamation was similar to the asthmatic group $(54.7 \pm 4.6 \%$ and $54.4 \pm 3.7 \%$, respectively). Subepithelial fibrosis was observed, although it was focal and irregularly distributed; however, owing to the presence of normal zones alternating with thicker zones, the apparent thickness of basement membrane was not statistically different from that of normal controls, with mean values of $4.6 \pm 0.1$ and $4.4 \pm 0.1 \mu \mathrm{m}$, respectively ( $p>0.05$ ). The histological appearance of the airway subepithelial area was similar to normal controls in regard to the number of inflammatory cells (fig. 1C). On electron microscopy, the basement membrane and subepithelial connective tissue were, most of the time, similar to control subjects, although a focal fibrosis was noted. A correlation was found between $\mathrm{PC} 20$ and percentage of epithelial desquamation $\left(\mathrm{r}_{\mathrm{S}}=-0.8\right.$, $\mathrm{p}=0.0001$ ) in this group.

\section{Airway inflammation: immunohistochemical analysis}

Biopsies of subjects with asymptomatic AHR showed increased numbers of $\mathrm{CD} 3+, \mathrm{CD} 8+$ and $\mathrm{CD} 25+\mathrm{T}-$ lymphocytes and of eosinophils (EG1+ and EG2+) compared with normal controls (fig. 2). The CD4/CD8 ratio of 

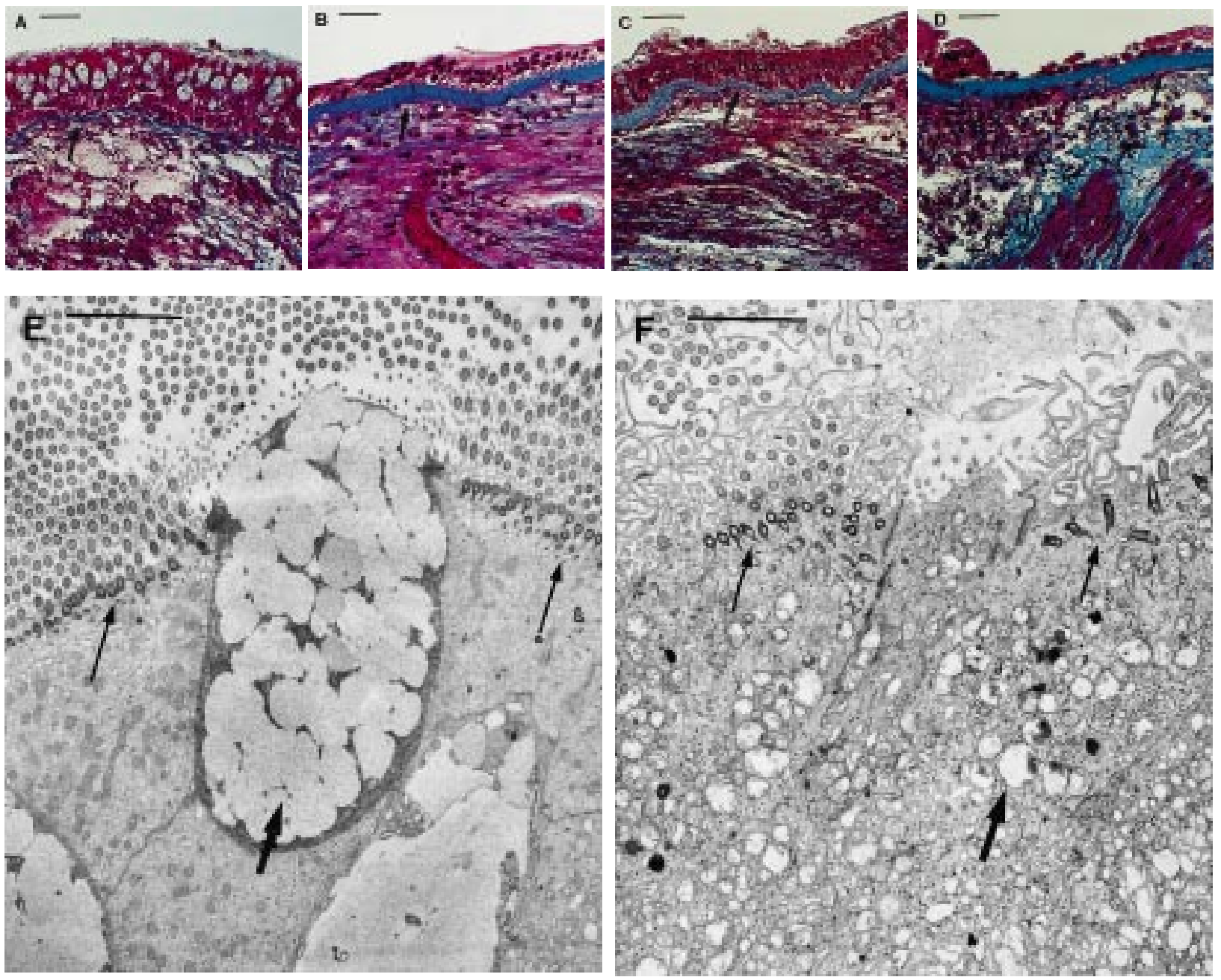

Fig. 1. - Histopathological features of bronchial biopsies in light micrographs (A-D, stained with Weigert-Masson trichrome) and electron micrographs (E and F, stained with lead citrate and uranyl acetate). A) A normal control subject showing pseudostratified citiated epithelium with goblet cells. Note a thin subepithelial collagen layer in blue (arrow) and few inflammatory cells. B) An asthmatic patient showing desquamated epithelial cell recovered with mucous material. The arrow indicates a thick layer of subepithelial fibrosis in blue. The subepithelial connective tissue is oedematous and contains numerous inflammatory cells, mainly lymphocytes. Two congested capillaries are observed. C) An asymptomatic airway hyperresponsive (AHR) subject showing epithelial cells covering a subepithelial fibrosis layer of variable thickness (arrow). The subepithelial area shows few inflammatory cells and little oedema. D) The same asymptomatic AHR subject as in (C) 2 yrs later. Note the epithelial cell desquamation, a thick and regular subepithelial collagen layer (arrow) and subepithelial oedema with inflammatory cells. There is a deposition of collagen fibres around smooth muscle cells. E) A normal control subject with numerous ciliated cells (small arrow) and goblet cells (large arrow). Note normal mitochondria. F) The same asymptomatic AHR subject as in (D) 2 yrs biopsy) showing impaired cilia genesis with basal corpuscules devoided of ciliae (small arrow). Note the dilatation of smooth endoplasmic reticulum (large arrow). (Internal scale bars $\mathrm{A}-\mathrm{D}=25 \mu \mathrm{m}, \mathrm{E}$ and $\mathrm{F}=5 \mu \mathrm{m}$.)

asymptomatic AHR subjects $(0.9 \pm 0.3)$ was lower than the one observed in asthmatic $(2.8 \pm 0.9, \mathrm{p}=0.07)$ and in normal control subjects $(4.7 \pm 1.3, \mathrm{p}=0.003)$. The subjects with asymptomatic AHR did not differ significantly from controls with regard to number of AA1, HLA-DR, CD45 or CD45Ro-positive cell counts (data not shown). In the asymptomatic AHR group, the mean $\mathrm{CD}_{45 \mathrm{Ro}+}$ and $\mathrm{CD} 8+$ cell counts were higher in atopic than in nonatopic subjects $(C D 45 R o+110.4 \pm 15.0$ and $49.7 \pm 13.0$, respectively, $\mathrm{p}=0.02 ; \mathrm{CD} 8+54.4 \pm 10$ and $13.9 \pm 2.7$ respectively, $\mathrm{p}=0.004$ ).

\section{Asymptomatic AHR subjects: follow-up}

Clinical and physiological parameters. At 2-yrs followup, four out of 10 subjects with asymptomatic AHR had developed asthma symptoms, including wheezing and exercise-induced cough in all four subjects, and wheezing and chest tightness when exposed to relevant allergens in three. All four were atopic (mean atopic index $5 \pm 0.7$ in asymptomatic AHR subjects who developed asthma symptoms, compared with $1.3 \pm 0.9$ in the others, $\mathrm{p}=0.02$ ), sensitized to indoor allergens and came from families with asthmatics. All asymptomatic AHR subjects who developed asthma symptoms were currently exposed to a domestic animal. Of the subjects in the asymptomatic AHR subgroup who did not develop asthma symptoms, only one was sensitized to indoor allergens, and this subject was exposed to an animal. With regard to the variability of the parameters in asymptomatic AHR subjects over the 2-yr period, FEV1 tended to decrease $(\mathrm{p}=0.07)$, serum $\operatorname{IgE}$ levels increased $(p=0.03)$ and airway responsiveness increased $(p=0.002)$ 

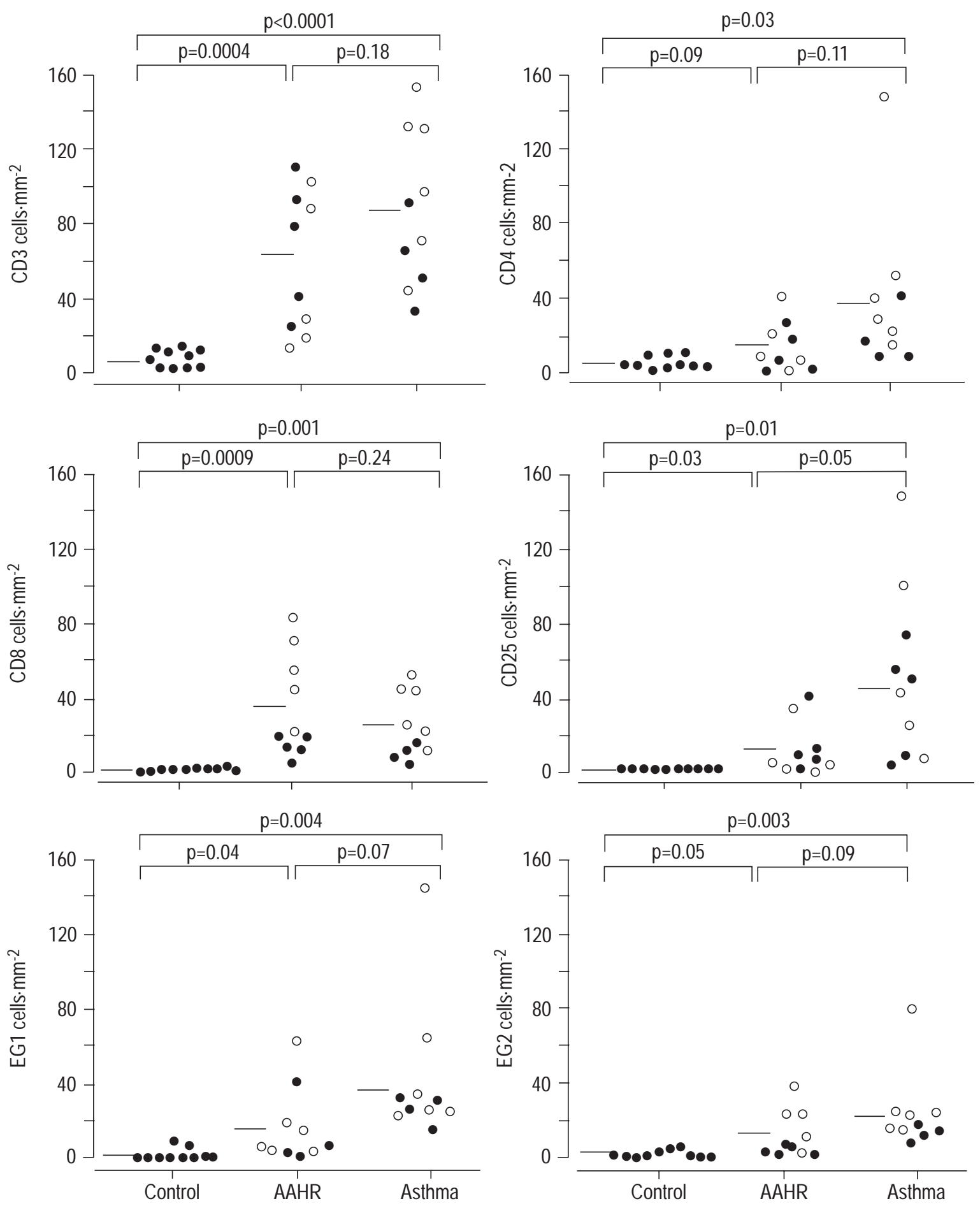

Fig. 2. - Inflammatory cell counts in bronchial biopsies of normal control, asymptomatic airway hyperresponsive (AAHR) and asthmatic subjects. The number of cells are expressed per square millimetre of connective tissue (see Methods section). $\bigcirc$ : atopic subjects; ๑: nonatopic subjects. Horizontal lines indicate means for the groups.

(table 2). The asymptomatic AHR subjects who developed asthma symptoms $(n=4)$ had a greater reduction of the $\mathrm{PC}_{20}$ than those who did not $\left(\triangle \mathrm{PC}_{20} 2.7 \pm 1.3\right.$ $\mu \mathrm{g} \cdot \mathrm{mL}^{-1}$ and $1.4 \pm 1.2 \mu \mathrm{g} \cdot \mathrm{mL}^{-1}$, respectively, $\left.\mathrm{p}=0.04\right)$ (fig. 3).

Airway histological changes. As one subject refused the second bronchoscopy at yr 2, a total of nine asympto- matic AHR subjects completed the study. After 2 yrs, asymptomatic AHR subjects who developed asthma symptoms showed an airway morphological appearance similar to that of the asthmatic subjects; the extent of epithelial desquamation was then similar in these two groups $(54.7 \pm 4.6 \%$ and $60.7 \pm 3.5 \%$, respectively $(p=0.2))$. Subepithelial fibrosis increased from a mean thickness of $4.6 \pm 0.1 \mu \mathrm{m}$ to $5.9 \pm 0.3 \mu \mathrm{m}(\mathrm{p}=0.001)$ and became 
Table 2. - Variability of the immunophysiological parameters in the asymptomatic airway hyperresponsive group over the 2-yr follow-up

\begin{tabular}{|c|c|c|c|c|c|}
\hline & $\begin{array}{l}\text { Eosinophils* } \\
\times 10^{9} \text { cells } \cdot \mathrm{L}^{-1}\end{array}$ & $\begin{array}{c}\mathrm{IgE}^{+} \\
\mathrm{mg} \cdot \mathrm{L}^{-1}\end{array}$ & $\begin{array}{l}\text { Atopic } \\
\text { index }\end{array}$ & $\begin{array}{l}\text { FEV1* } \\
\% \text { pred }\end{array}$ & $\begin{array}{c}\mathrm{PC}_{20}{ }^{+} \\
\mathrm{mg} \cdot \mathrm{mL}^{-1}\end{array}$ \\
\hline Baseline $(n=10)$ & $0.23 \pm 0.04$ & $178.7 \pm 1.3$ & $2.8 \pm 0.8$ & $95 \pm 2.4$ & $3.6 \pm 1.1$ \\
\hline Year $2(n=10)$ & $0.33 \pm 0.11$ & $257.0 \pm 1.3$ & $2.8 \pm 0.8$ & $92.1 \pm 1.9$ & $2.0 \pm 1.2$ \\
\hline p-value & $>0.05$ & 0.03 & $>0.05$ & 0.07 & 0.003 \\
\hline
\end{tabular}

IGE: immunoglobulin E; FEV1: forced expiratory volume in one second; PC20: provocative concentration of methacholine causing a $20 \%$ fall in FEV1. *: expressed as mean \pm SEM; ${ }^{+}$: expressed as geometric mean \pm SEM; ${ }^{*}$ : number of main categories of allergens presenting at least one positive response (total of six categories).

uniformly distributed (fig. 1D). This increase in subepithelial fibrosis was closely associated with the atopic status. In fact, this increase in subepithelial fibrosis went respectively from $4.5 \pm 0.4$ to $6.5 \pm 0.6 \mu \mathrm{m}$ ( $\mathrm{p}=$ 0.002 ) for atopic asymptomatic AHR, compared with $4.3 \pm 0.2$ to $5.2 \pm 0.5 \mu \mathrm{m}(\mathrm{p}=0.12)$ for nonatopic asymptomatic AHR ( $\mathrm{p}=0.06)$. Furthermore, this increase in subepithelial fibrosis was correlated with the reduction in $\mathrm{PC} 20\left(\mathrm{r}_{\mathrm{s}}=0.78, \mathrm{p}=0.03\right.$, fig. $\left.4 \mathrm{a}\right)$. Inflammatory cells were numerous in the airway wall connective tissue, and eosinophils and mast cells were often degranulated. On electron microscopy, the remaining epithelial cells showed incomplete cilia genesis (figs. 1D and F). Many cells were completely devoid of cilia. Compared to the control subjects (fig. 1E), mitochondrial swelling was evident as well as dilatation of smooth endoplasmic reticulum (fig. 1F). Subepithelial fibrosis was also obvious.

Airway inflammation: immunohistochemistry. In the asymptomatic AHR group, the numbers of CD4+ and CD25+ cells increased significantly over the 2-yr period $(\mathrm{p}<0.05)$, whereas CD8+ cell counts decreased $(\mathrm{p}=0.06$, fig. 5). The $\mathrm{CD} 4 / \mathrm{CD} 8$ ratio increased from $0.9 \pm 0.3$ to $2.1 \pm 0.5(\mathrm{p}=0.06)$. The number of EG1+ and EG2+ eosinophils also increased $(\mathrm{p}=0.07$ and $\mathrm{p}=0.08$, respec-

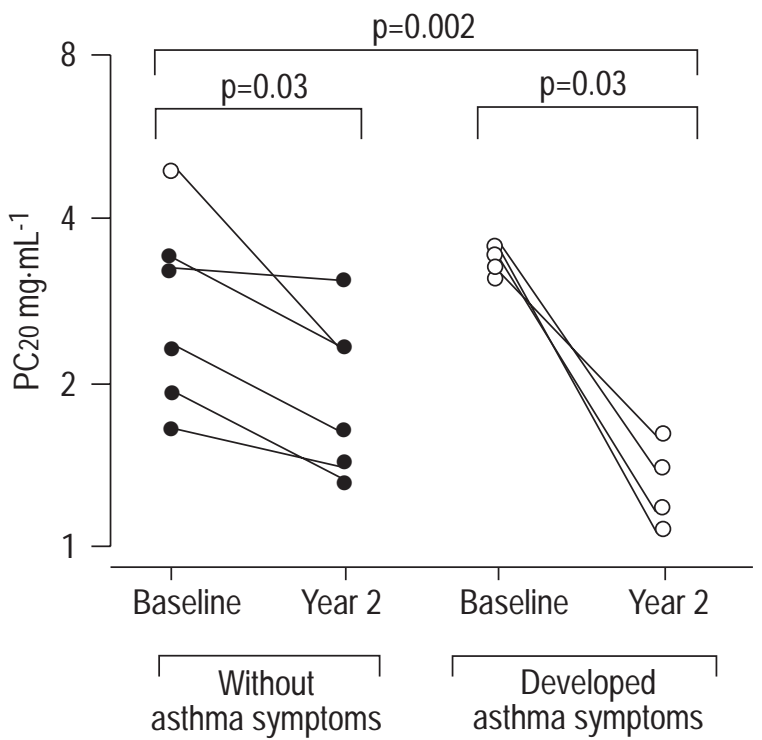

Fig. 3. - Provocative concentration of methacholine causing a $20 \%$ fall in forced expiratory volume in one second (PC20) at baseline and followup evaluations in asymptomatic airway hyperresponsive subgroups: those who developed asthma symptoms and those who did not. $\bigcirc$ : atopic subjects; $\bigcirc$ : nonatopic subjects. tively), whereas AA1+, HLA-DR+, CD45+, CD45Ro+ cell counts were unchanged over the 2-yr follow-up (data not shown).

The changes in CD4+, CD25+ and CD8+ observed over the follow-up period were more pronounced in subjects developing symptoms of asthma who also presented a significant increase of $\mathrm{CD} 3+$ cells (fig. 5). The concomitant increase of CD4+ cells and decrease of CD8+ cells in the subjects who developed asthma symptoms resulted in a significant increase of the CD4/CD8 ratio from $0.3 \pm 0.1$ to $3.8 \pm 0.5(\mathrm{p}=0.01)$, and this ratio became similar to the one observed in the asthmatic group $(3.8 \pm 0.5$ and $2.8 \pm 0.9$, respectively, $\mathrm{p}=0.52)$. This ratio did not change in the subjects who did not develop asthma symptoms $(1.2 \pm 0.5$ to $0.9 \pm 0.2 ; p=0.47)$. Furthermore, in the nine subjects who had two bronchoscopies, a correlation between the degree of change in $\mathrm{PC}_{2} 0$ and the increase in CD4/CD8 ratio was observed $\left(r_{s}=0.75, p=\right.$ 0.03 , fig. $4 b)$.

\section{Discussion}

To the authors' knowledge, this is the first study evaluating changes in bronchial immunohistological parameters before and after the appearance of asthma symptoms in a group of subjects at high-risk of developing symptomatic asthma: those with asymptomatic AHR. At the initial evaluation, these asymptomatic AHR subjects had evidence of mild airway inflammatory and structural changes similar in nature to those observed in asthmatic subjects, although of a lesser magnitude. Their bronchial biopsies showed epithelial damage, an increased number of activated lymphocytes and eosinophils, and focal deposition of collagen under the epithelial basement membrane suggesting an active airway remodelling process. Over the 2-yr follow-up, AHR and subepithelial fibrosis increased significantly. Their bronchial mucosa CD4+ and CD25+ cell counts were also augmented whereas their CD8+ cell counts decreased. Four out of the 10 subjects studied developed asthma symptoms. Compared with the six subjects who did not develop asthma symptoms, these four presented with a greater increase in AHR and in subepithelial fibrosis, a greater increase in $\mathrm{CD} 3+, \mathrm{CD} 4+$ and CD25+ cell counts, and a greater reduction in numbers of CD8+ cells. Consequently, the development of asthma symptoms seems associated with an increased subepithelial collagen deposition and CD4/ CD8 ratio. Interestingly, all of these phenomena occurred in subjects who were sensitized and continuously exposed to indoor allergens and who came from asthmatic families. 


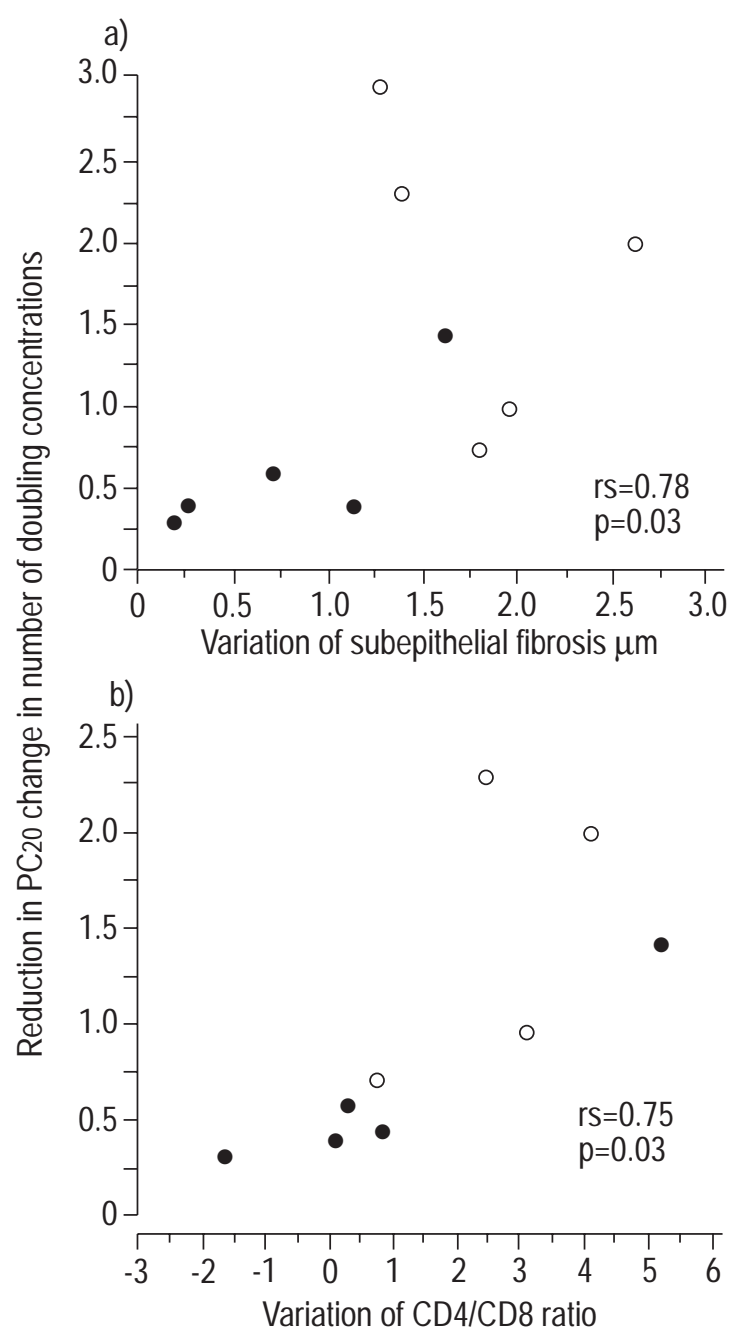

Fig. 4. - Relationship between the increase in airway responsiveness and a) airway subepithelial fibrosis and b) variation of CD4/CD8 ratio over the 2-yr follow-up; $\bigcirc$ : atopic subjects; $\bigcirc$ : nonatopic subjects. One subject did not agree to a second bronchoscopy. PC20: provocative concentration of methacholine causing a $20 \%$ fall in forced expiratory volume in one second.

Airway inflammatory and structural changes have been observed in very mild asthma and asthma-related conditions such as allergic rhinitis [24, 25]. In the present study, the asymptomatic AHR subjects, matched for the degree of airway responsiveness to asthmatic subjects, had increased epithelial desquamation, subepithelial deposition and numbers of inflammatory cells, especially eosinophils and lymphocytes, compared with normal control subjects. The histological features were relatively close to the ones previously described in nonasthmatic atopic subjects without, or with only, bordeline AHR [25], and they were less intense than those observed in asthmatics.

Some studies $[15,26]$ but not others [27-29], found a correlation between AHR and airway cellular infiltrate in asthmatic subjects, although it has been reported with epithelial damage $[27,30]$. In the present subjects with asymptomatic AHR, even though the number of subjects is small, no association was found between the inflammatory cell counts and the degree of AHR. This however, does not eliminate the possibility that airway inflamma- tion is a significant determinant of AHR. A correlation between the extent of subepithelial fibrosis and the presence of AHR in groups of subjects with asthma and related diseases was recently reported [31], suggesting that another aspect of airway remodelling, airway fibrosis, was a potential determinant or marker of a process that leads to the development of AHR. At baseline, in asymptomatic AHR subjects, no correlation between the degree of AHR and that of the measured focal subepithelial fibrosis was found.

The asymptomatic AHR subjects with atopy had a higher bronchial CD45Ro+ cell count than the nonatopic asymptomatic AHR subjects at baseline; as previously observed this supports a finding by ACKERMAN et al. [32] that there is an increase of memory T-cells in atopic subjects. The atopic asymptomatic AHR subjects also had a higher number of CD8+ cells (fig. 2). AzzAw et al. [15] reported a predominance of CD4+ over CD8+ cells in the subepithelial area of asthmatic, nonasthmatic atopic and control biopsies, as was observed in the present control and asthmatic groups. GonzALEz et al. [33], however, observed a low CD4/CD8 ratio in the bronchoalveolar lavage of single early responders compared to dual (early and late) responders after allergen challenge. Their results suggested that CD8+ cells could prevent the development of the late-phase reactions by a mechanism yet to be defined. These observations suggest the possibility that an increase in CD8+ cell counts in asymptomatic AHR subjects may prevent, at least temporarily, or minimize, the cascade of events leading to the development of symptomatic asthma.

This hypothesis is further strengthened by the fact that subjects with asymptomatic AHR who developed asthma symptoms presented a significant increase of inflammatory cells with a decreased number of CD8+ cells, their CD4+/ CD8+ ratio becoming similar to that of the asthmatic group. Hence, the development of asthma symptoms in subjects with asymptomatic AHR appears to be associated with a specific modification in T-cell subsets, although the mechanisms involved in these changes remain unclear. The appearance of asthma symptoms was also temporarily associated with an increase of AHR and subepithelial fibrosis. Consequently, it seems plausible that the increased collagen deposition underneath the basement membrane may potentiate airway narrowing in response to a stimulus or prevent reflex bronchodilatation after a maximal inspiratory manoeuvre [34]. It seems possible that, in subjects with a genetic predisposition, the presence of atopy and continuous exposure to indoor allergens and/or intercurrent respiratory viral infections modifies the inflammatory process, increasing inflammatory cell numbers, particularly CD4+ lymphocytes and eosinophils, decreasing CD8+ lymphocyte counts, inducing structural changes and progressive collagen deposition and enhancing AHR (fig. 4a and b). In this regard, the role of viral infection in this setting should be further explored [35]. The appearance of asthma symptoms among nonatopic subjects who had first-degree relatives with asthma was not observed. However, it seems possible that these subjects could develop asthma symptoms over a longer follow-up. They probably present other genetic and/or environmental predisposing factors to developing AHR, then atopy and eventually asthma symptoms. 

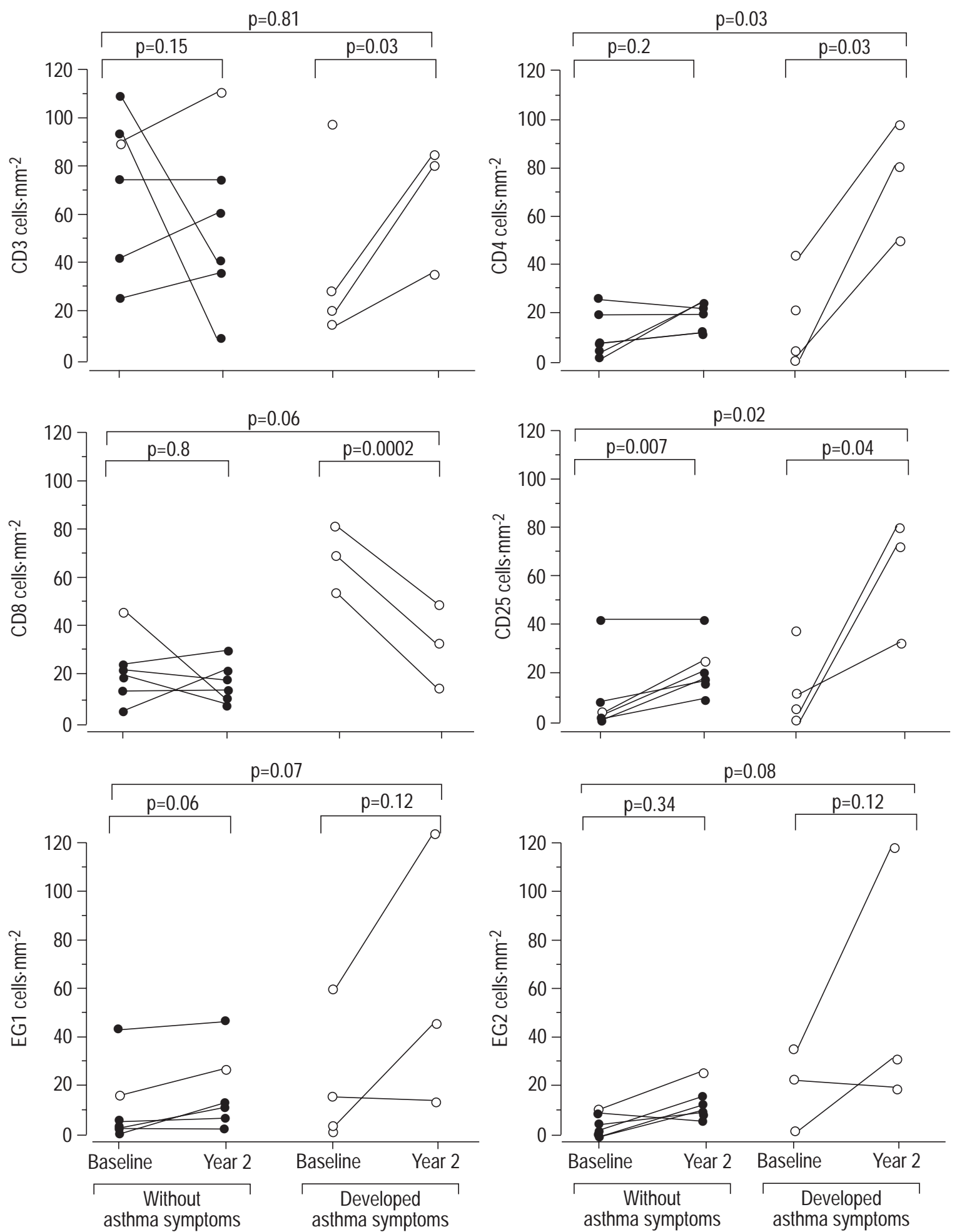

Fig. 5. - Inflammatory cell counts in bronchial biopsy of asymptomatic airway hyperresponsive subjects at baseline and follow-up. One subject did not complete the study who was in subgroup which developed asthma symptoms. O: atopic subjects; $\bigcirc$ : nonatopic subjects.

The recruitment of the asymptomatic AHR subjects in this study was made possible by a large epidemiological study [10]. Of major value in this study is the fact that the subjects with asymptomatic AHR with and with-out atopy were evaluated over a 2-yr follow-up before and after four of them developed asthma symptoms. Although the number of subjects is limited, significant modifications of clinical, physiological and histological parameters could be observed, allowing the evaluation of the potential role of airway inflammation and structural changes in the development of symptomatic asthma. These results have major clinical relevance, as they 
suggest basic mechanisms involved in asymptomatic AHR and in the development of symptomatic asthma in atopic subjects with asymptomatic AHR.

In conclusion, airway inflammation and airway remodelling were observed in bronchial biopsy specimens of asymptomatic airway hyperresponsive subjects. This inflammation is characterized by eosinophil and T-lymphocyte infiltration. In these subjects, atopy and familial history of asthma are associated with a higher risk of developing symptomatic asthma over a short-term followup, and this supports earlier findings on the role of these environmental and genetic factors in the pathogenesis of asthma. The mechanisms by which this asymptomatic phase of airway hyperresponsiveness becomes overt symptomatic asthma remain to be documented, but the associated increased inflammatory cell infiltrate and subepithelial fibrosis over the years may suggest that these bronchial alterations are involved in this phenomenon. Further studies are needed to define the role of the cells and mediators involved in these changes. Moreover, this study suggests that, in asymptomatic airway hyperresponsive subjects with atopy and a familial history of asthma, preventive measures, such as avoidance of sensitizing substances, may reduce airway inflammation and prevent the development of symptomatic asthma. Further work should nevertheless be performed to confirm these observations and determine their clinical significance.

\begin{abstract}
Acknowledgements. The authors thank all subjects for their participation in this study and especially the nurses for collaboration in gathering blood samples and helping with the bronchoscopies.
\end{abstract}

\section{References}

1. Woolcock AJ. What is bronchial hyperresponsiveness from the clinical standpoint? In: Page CP, Gardiner PJ, eds. Airway Hyperresponsiveness: is it Really Important for Asthma? Oxford, Blackwell Scientific Publications, 1993; pp. 1-9.

2. Cockcroft DW, Berscheid BA, Murdock KY. Unimodal distribution of bronchial responsiveness to inhaled histamine in a random population. Chest $1983 ; 8: 751-754$.

3. Hopp RJ, Townley RG, Biven RE, Bewtra AK, Nair NM. The presence of airway reactivity before the development of asthma. Am Rev Respir Dis 1990; 141: 2-8.

4. Hoop RJ, Bewtra AK, Nair NM, Biven R, Townley RG. Pattern of methacholine-induced bronchial reactivity in siblings of asthmatic subjects. Pediatr Asthma Allergy Immunol 1987; 1: 103-109.

5. Hopp RJ, Bewtra AK, Biven R, Nair NM, Townley RG. Bronchial reactivity pattern in nonasthmatic parents of asthmatics. Ann Allergy 1988; 61: 18406.

6. Hopp RJ, Brennan B, Degan J, Biven RE, Bewtra AK, Townley RG. Longitudinal measurement of nonspecific bronchial hyperresponsiveness in non-allergic children and adolescents. Pediatr Allergy Immunol 1992; 3: 8490.

7. Muller BA, Leick CA, Smith RM, Suelzer MT, Richerson HB. Comparisons of specific and non-specific bronchoprovocation in subjects with asthma, rhinitis, and healthy subjects. J Allergy Clin Immunol 1993; 91: 758-772.
8. Cockcroft DW, Murdock KY, Berscheid BA. Relationship between atopy and bronchial responsiveness to histamine in a random population. Ann Allergy 1984; 53: 26-29.

9. Braman SS, Burrows AA, DeCotiis BA, Settipane GA, Corrao WM. Airway hyperresponsiveness in allergic rhinitis: a risk factor for asthma. Chest 1987; 91: 671-674.

10. Laprise C, Boulet L-P. Asymptomatic airway hyperresponsiveness: a 3-year follow-up. Am J Respir Crit Care Med 1997; 156: 1-7.

11. Hargreave FE, Ramsdale EH, Kirby JG, O'Byrne PM. Asthma and the role of inflammation. Eur J Respir Dis 1986; 69: Suppl. 147, 16-21.

12. Reid LM, Gleich GJ, Hogg J, Kleinermann J, Laitinen LA. Pathology. In: Holgate ST, ed. The Role of Inflammatory Process in Airway Responsiveness. Oxford, Blackwell Scientific Publications, 1989; pp. 36-79.

13. Laitinen LA, Heino M, Laitinen A, Kava T, Haahtela T. Damage of the airway epithelium and bronchial reactivity in patients with asthma. Am Rev Respir Dis 1985; 131: 559-606.

14. Jeffery PK, Wardlaw AJ, Nelson FC, Collins JV, Kay AB. Bronchial biopsies in asthma. An ultrastructural, quantitative study and correlation with hyperreactivity. Am Rev Respir Dis 1989; 140: 1745-1753.

15. Azzawi M, Bradley B, Jeffery PK, et al. Identification of activated $\mathrm{T}$ lymphocytes and eosinophils in bronchial biopsies in stable atopic asthma. Am Rev Respir Dis 1990; 142: $1407-1413$.

16. Power C, Streenan S, Hurson B, Burke C, Poulter LW. Distribution of immunocompetent cells in the bronchial wall of clinically healthy subjects showing bronchial hyperresponsiveness. Thorax 1993; 48: 1125-1129.

17. American Thoracic Society. Standards for the diagnosis and care of patients with chronic obstructive pulmonary disease (COPD) and asthma. Am Rev Respir Dis 1987; 136: 225-244.

18. Malo JL, Pineau L, Carrier A, Martin RR. Reference values of the provocative concentrations of methacholine that cause $6 \%$ and $20 \%$ changes in forced expiratory volume in one second in a normal population. Am Rev Respir Dis 1983; 128: 8-11.

19. Sub-Committee on skin tests of the European Academy of Allergology and Clinical Immunology. Skin tests used in type I allergy testing. Position paper. Allergy 1989; 44: Suppl. 10, 1-59.

20. American Thoracic Society. Standardization of spirometry. Am J Respir Crit Care Med 1994; 152: 1107-1136.

21. Juniper E, Cockcroft DW, Hargreave FE. Histamine and Methacholine Inhalation Tests: Tidal Breathing Method. Laboratory Procedure and Standardization. Canadian Thoracic Society. Lund, Sweden, AB Draco, 1991.

22. Karnovsky MJ. A formaldehyde-glutaraldehyde fixative for high osmolarity for use in electron microscopy. $J$ Cell Biol 1965; 27: 137A.

23. Britten KM, Howarth PH, Roche WR. Immunochemistry on resin sections: a comparison of resin embedding. Technique for mucosal biopsies. Biotech Histochem 1993; 68: 271-280.

24. Djukanovic R, Lai CKW, Wilson JW, et al. Bronchial mucosal manifestations of atopy: a comparison of markers of inflammation between atopic asthmatics, atopic nonasthmatics and healthy controls. Eur Respir J 1992; 5: 538-544.

25. Chakir J, Laviolette M, Boutet M, Laliberté R, Dubé J, Boulet L-P. Lower airways remodelling in nonasthmatic subjects with allergic rhinitis. Lab Invest 1996; 75: 1-10. 
26. Sont JK, Van Krieken JHJM, Evertse CE, Hooijer R, Willems LNA, Sterk PJ. Relationship between the inflammatory infiltrate in bronchial biopsy specimens and clinical severity of asthma in patients treated with inhaled steroids. Thorax 1996; 51: 496-502.

27. Djukanovic R, Roche WR, Wilson JW, et al. Mucosal inflammation in asthma. Am Rev Respir Dis 1990; 142: 434-457.

28. Bradley BL, Azzawi M, Jacobson M, et al. Eosinophils, T lymphocytes, mast cells, neutrophils, and macrophages in bronchial biopsy specimens from atopic subjects with asthma: comparison with biopsy specimens from atopic subjects without asthma and normal control subjects and relationship to bronchial hyperresponsiveness. J Allergy Clin Immunol 1991; 88: 661-674.

29. Ollerenshaw SL, Woolcock AJ. Characteristics of the inflammation in biopsies from large airways of subjects with asthma and subjects with chronic airflow limitation. Am Rev Respir Dis 1992; 145: 922-927.

30. Jeffery PK, Wardlaw AJ, Nelson FC, Collins JV, Kay AB. Bronchial biopsies in asthma. An ultrastructural, quanti- tative study and correlation with hyperreactivity. Am Rev Respir Dis 1989; 140: 1745-1753.

31. Boulet LP, Laviolette M, Tricot H, et al. Bronchial subepithelial fibrosis correlates with airway responsiveness to methacholine. Chest 1997; 112: 45-52.

32. Ackerman V, Marini M, Vittori E, Bellini A, Vassali G, Mattoli S. Detection of cytokines and their cell sources in bronchial biopsy specimens from asthmatic patients: relationship to atopic status, symptoms, and level of airway hyperresponsiveness. Chest 1994; 105: 687-696.

33. Gonzalez MC, Diaz P, Galleguillos FR, Ancic P, Cromwell $\mathrm{O}$, Kay AB. Allergen-induced recruitment of bronchoalveolar helper (OKT4) and suppressor (OKT8) Tcells in asthma. Am Rev Respir Dis 1987; 136: 600-604.

34. Skloot G, Permutt S, Togias A. Airway hyperresponsiveness in asthma: a problem of limited smooth muscle relaxation with inspiration. J Clin Invest 1995; 96: 23932403.

35. Alwan WH, Kozlowska WJ, Openshaw PMJ. Distinct types of lung disease caused by functional subsets of antiviral T cells. $J$ Exp Med 1994; 179: 81-89. 